\title{
Modeling the innovative component of sustainable development of oil and gas enterprises. The case of PJSC ROSNEFT
}

\author{
Nina Baranova*, and Daria Loginova \\ Peoples' Friendship University of Russia (RUDN University), Miklukho-Maklaya Str, 6, 117198 \\ Moscow, Russia
}

\begin{abstract}
PJSC ROSNEFT is a member of the UN Global Compact since 2010 and supports the UN Sustainable Development Goals. In the Strategies-2022 (2030), important directions are recorded in which PJSC ROSNEFT will develop. A significant place in them is given to innovative development as an important component of sustainable development. The corporation set a new record in Russia for oil production in 2019 thanks to these developments - 560.3 million tons - and did not go broke in 2020. In our work, we will conduct a study of the innovative component of the corporation's sustainable development in 2004-2020. To this end, the materials of annual and consolidated reports, programs of sustainable and innovative development for 2004-2020 were studied. The Eviews10 econometrics software was used to carry out econometric modeling. The work shows that the obtained linear model is adequate and can be used for predictive calculations for the short term. The exponential model turned out to be inadequate for calculations. The article notes that epidemics, oil and gas wars, geopolitical contradictions have significantly reduced the rate of economic growth of PJSC ROSNEFT. The corporation will have to adjust its sustainable and innovative development programs to reduce costs, stop falling income and return to the previous level of development.
\end{abstract}

\section{Introduction}

PJSC ROSNEFT is one of the largest companies in the Russian and world oil and gas market. PJSC ROSNEFT entered the Top-10 Russian oil companies (3rd place) in extraction and processing of oil in 2013 as a result of the takeover of TNK-BP plc and the acquisition of Bashneft (2016). The revenue and profit of PJSC ROSNEFT amounted to 6,850 billion rubles and 549 billion rubles in 2018. PJSC ROSNEFT took 1st place in this rating (revenue of 8676 billion rubles, profit of 708 billion rubles) in 2019 [22].

PJSC ROSNEFT ranked 158th in 2016 (revenue of $\$ 56.553$ billion), 115th place in 2017 (revenue of $\$ 72.028$ billion), 86th place in 2018 (revenue of $\$ 90.055$ billion), 76th place in 2019 (revenue of \$ 96.313 billion) [23] according to the Fortune Global 500 magazine.

PJSC ROSNEFT has formed a competitive portfolio of gas projects and ranked 3rd in gas production in Russia. The corporation has developed and is actively implementing this 
portfolio [1] in various regions of Russia and the world: Germany, Norway, Italy, Spain, Japan, China, Mongolia, Vietnam, India, etc.

PJSC ROSNEFT is a member of the UN Global Compact and supports the UN Sustainable Development Goals since 2010. In the Strategies-2022 (2030) [2-3] important directions in which the company will develop are recorded. A significant place in them is given to innovative development as an important component of sustainable development [34]. The corporation set a new record in Russia for oil production in 2019 thanks to these developments -560.3 million tons.

\section{Innovative activity of PJSC ROSNEFT}

In their works Russian and foreign scientists [4-12] have proved that innovative technologies are the main component of the competitiveness of both an enterprise and a country. PJSC ROSNEFT pays special attention to the innovation and the introduction of breakthrough technologies in production. A certified audit in the field of innovation management and international standards have determined the company's innovative activities of sustainable development. These directions are formulated in the PJSC ROSNEFT Innovative and Sustainable Development Program for 2016-2020 with a vision to $2030[3,13]$.

PJSC ROSNEFT develops its own scientific research complex (27 Research and Design Institutes), cooperates with industry research institutes, universities, small and mediumsized innovative enterprises. The scope of work of the corporate research and development complex has more than doubled since 2016.

Advanced inventions, unique innovative projects of PJSC ROSNEFT are significant both for the corporation and for the entire oil and gas industry in Russia and abroad. 4,274 patent applications were filed in 2017, of which 1,355 were implemented, and the economic effect from the use of patent rights was more than 3.8 billion rubles; 700 million rubles were allocated for the implementation and distribution of innovative technologies in 2018. The share of the Company's projects implemented in its own software has doubled. The confirmed economic effect from the implemented targeted innovative projects for 20172019 amounted to more than 36 billion rubles.

The unique innovative R\&D of the Company, comparable or unparalleled abroad, were carried out in the field of exploration and production, high-tech technological software, oil refining and petrochemicals, development of polymer materials for oil production, production of equipment and services, environmental protection, etc.

According to annual reports, reports in the field of sustainable development and press releases [14-15], PJSC ROSNEFT has recently increased its costs for innovative development. Total investments in innovative projects for 2016-2019 amounted to 250 billion rubles, of which R\&D costs were 92 billion rubles: R\&D costs increased by $48 \%$ ( 29.9 billion rubles) in 2017 , by $7.4 \%$ (32.1 billion rubles) in 2018 and decreased to 30 billion rubles in 2019 . The share of patent applications increased by $30 \%$, and the economic effect from the use of patent rights amounted to 16.7 billion rubles. More than 640 patents were developed, 279 new technologies were tested ( 78 were introduced), and the economic effect from the introduction of new technologies amounted to 659 million rubles in 2019. 


\section{Econometric modeling of innovation activity of PJSC ROSNEFT}

In the long-term development program of PJSC ROSNEFT until 2030 [2-3], the indicator of innovative activity, among the main indicators aimed at solving the company's strategic objectives, is indicated.

The statistical data of the annual reports of PJSC ROSNEFT for 2004-2020 [3, 13-16] were used to determine the level of the development of the company's innovative activity, its competitiveness. Linear, exponential models were built using the Eviews10 software package [17-20]. These models are necessary to calculate the forecast of innovative development of PJSC ROSNEFT for the short term.

Variables were entered. $Y\left(R \_D\right)$ is the $R \& D$ costs (billion rubles) and characterizes the level of innovation activity of the corporation. Variables $\mathrm{X}_{1}(\mathrm{CAP})$ is the market capitalization of the corporation (billion rubles), $\mathrm{X}_{2}$ (NATUR) is environmental costs (billion rubles), $\mathrm{X}_{3}(\mathrm{REV})$ is sales revenue (billion rubles) have the power to change Y(R_D). The modeling will be carried out using statistical data for 2005-2019 $(n=15)$.

\begin{tabular}{|c|c|c|c|c|}
\hline $\begin{array}{l}\text { Correlation } \\
\text { t-Statistic } \\
\text { Probability } \\
\end{array}$ & R D & CAP & NATUR & REV \\
\hline R_D & 1.000000 & & & \\
\hline & $\overline{-}$ & & & \\
\hline CAP & $\begin{array}{r}0.951277 \\
1.723519 \\
0.1085\end{array}$ & 1.000000 & & \\
\hline NATUR & $\begin{array}{r}0.919513 \\
8.434725 \\
0.0000\end{array}$ & $\begin{array}{r}0.476337 \\
3.310611 \\
0.0056\end{array}$ & 1.000000 & \\
\hline REV & $\begin{array}{r}0.899996 \\
7.444367 \\
0.0000\end{array}$ & $\begin{array}{r}0.577882 \\
3.718033 \\
0.0026\end{array}$ & $\begin{array}{r}0.437144 \\
11.91605 \\
0.0000\end{array}$ & 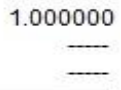 \\
\hline
\end{tabular}

Fig. 1. Covariance analysis

A matrix of pairwise correlations is built (Fig. 1) to determine the strength of relationships between variables $\mathrm{X}_{1}(\mathrm{CAP}), \mathrm{X}_{2}(\mathrm{NATUR}), \mathrm{X}_{3}(\mathrm{REV})$ and variable $\mathrm{Y}(\mathrm{R}$ D $)$. Here the correlation is established between $\mathrm{Y}\left(\mathrm{R}_{-} \mathrm{D}\right)$ and $\mathrm{X}_{1}(\mathrm{CAP}), \mathrm{X}_{2}(\mathrm{NATUR}), \mathrm{X}_{3}(\mathrm{REV})$ as follows: $r_{\mathrm{yx} 1}=0.95 ; r_{\mathrm{yx} 2}=0.912 ; \mathrm{r}_{\mathrm{yx} 3}=0.9$. There is a slight multicollinearity between the variables $\mathrm{X}_{1}(\mathrm{CAP}), \mathrm{X}_{2}$ (NATUR), $\mathrm{X}_{3}(\mathrm{REV})\left(\mathrm{r}_{\mathrm{x} 1 \times 2}=0.48 ; \mathrm{r}_{\mathrm{x} 1 \times 3}=0.58, \mathrm{r}_{\mathrm{x} 2 \times 3}=0.44\right)$, so it could be happened a bit wrong result. Therefore, the parameters are studied, and the desired equation is estimated. 


\begin{tabular}{|c|c|c|c|c|}
\hline Variable & Coefficient & Std. Error & $\mathrm{t}$-Statistic & Prob. \\
\hline CAP & -0.005780 & 0.001441 & -4.011513 & 0.0020 \\
\hline NATUR & 0.698288 & 0.281665 & 2.479141 & 0.0306 \\
\hline REV & 0.002852 & 0.001298 & 2.198007 & 0.0503 \\
\hline $\mathrm{C}$ & 11.88991 & 3.280191 & 3.624762 & 0.0040 \\
\hline R-squared & 0.939187 & \multicolumn{2}{|c|}{ Mean dependent var } & 16.66400 \\
\hline Adjusted R-squared & 0.922601 & \multicolumn{2}{|c|}{ S.D. dependent var } & 12.84708 \\
\hline S.E. of regression & 3.574145 & \multicolumn{2}{|c|}{ Akaike info criterion } & 5.608507 \\
\hline Sum squared resid & 140.5196 & \multicolumn{2}{|c|}{ Schwarz criterion } & 5.797321 \\
\hline Log likelihood & -38.06381 & \multirow{2}{*}{\multicolumn{2}{|c|}{$\begin{array}{l}\text { Hannan-Quinn criter. } \\
\text { Durbin-Watson stat }\end{array}$}} & 5.606496 \\
\hline F-statistic & 56.62699 & & & 1.818801 \\
\hline Prob(F-statistic) & 0.000001 & & & \\
\hline
\end{tabular}

Fig. 2. The coefficients and estimates of the linear equation (1)

The Eviews10 software package is used to obtain the coefficients of the linear model and estimate the parameters of the equation. The coefficients and parameter estimates show (Fig. 2) that the equation is significant $\left(\mathrm{F}_{\text {stat }}=56.63\right.$, p-value $\left.=0.000\right)$ and can be used for forecasting for the short term. The coefficient of determination is $\mathrm{R}^{2}=0.939$ Thus, the obtained linear model is adequate according to the formal criterion. The equation for analysis and forecast is as follows:

$Y^{\wedge}\left(R \_D\right)=-0.0058 \cdot X_{1}(C A P)+0.7 \cdot X_{2}(N A T U R)+0.0029 \cdot X_{3}(R E V)+11.89$

Further, the regression coefficients are examined: an increase in the market capitalization of an enterprise by 1 billion rubles will lead to a change in R\&D by an average of 5.8 million rubles per year; an increase in environmental projects costs by 1 billion rubles will lead to an increase in $\mathrm{R} \& \mathrm{D}$ by an average of 700 million rubles per year; an increase in sales revenue by 1 billion rubles will lead to an increase in R\&D by an average of 2.9 million rubles per year, other things being equal. If $\mathrm{X}_{1}(\mathrm{CAP})=\mathrm{X}_{2}$ (NATUR) $=\mathrm{X}_{3}(\mathrm{REV})=0$, then $\mathrm{Y}^{\wedge}\left(\mathrm{R} \_\mathrm{D}\right)=11.89$.

The T-statistic of each variable and their Prob are adequate (Fig. 2), therefore, the obtained components can be used for further analysis and forecast. The fitted values of $\mathrm{Y}^{\wedge}\left(\mathrm{R}_{-} \mathrm{D}\right)$, on average, approximate well the dependence of $\mathrm{Y}\left(\mathrm{R} \_\mathrm{D}\right)$ on the variables $\mathrm{X}_{1}(\mathrm{CA} P), \mathrm{X}_{2}$ (NATUR), $\mathrm{X}_{3}(\mathrm{REV})$. Considering the Jacques-Bera test (Fig. 3), it can be argued that the residuals of the equation (1) have normal distribution (0.35), and the probability of accepting the null hypothesis $\mathrm{H}_{0}$ is $84 \%$ ( $\mathrm{P}$-value $\left.=0.84\right)$.

\begin{tabular}{|lc|}
\hline \multicolumn{2}{|l|}{ Series: Residuals } \\
Sample 2005 & 2019 \\
Observations & 15 \\
Mean & $4.03 \mathrm{e}-15$ \\
Median & 0.202608 \\
Maximum & 6.064469 \\
Minimum & -5.375159 \\
Std. Dev. & 3.168141 \\
Skewness & -0.038810 \\
Kurtosis & 2.260723 \\
& \\
Jarque-Bera & 0.345347 \\
Probability & 0.841412 \\
\hline
\end{tabular}

Fig. 3. Jarque-Bera test 
Theil's coefficient $(0<0.074<1)$ and the mean absolute percent error of the equation $(12.89 \%)$ show the high accuracy of the model (1) (Fig. 4).

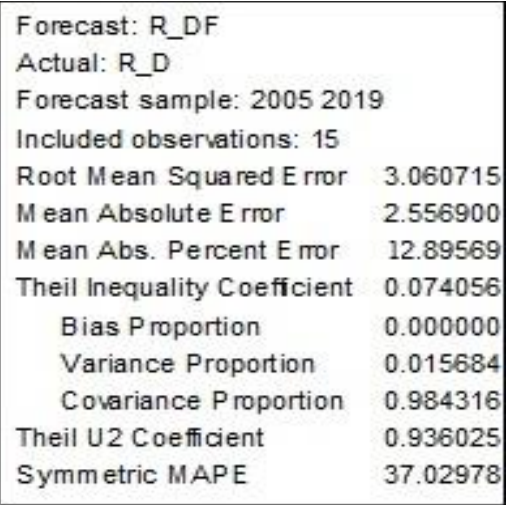

Fig. 4. Parameters of the model (1)

The White test investigates the model (1) for the absence of heteroscedasticity. Hypothesis $\mathrm{H}_{0}$ : the proposition that the residuals of the equation (1) are not homoscedastic, $\mathrm{H}_{1}$ is the opposite hypothesis. According to White test (Fig. 5), it can be argued that the value oftheObs* $\mathrm{R}^{2}=12.5$, and the corresponding $\mathrm{P}$-value is 0.19 , i.e. the hypothesis $\mathrm{H}_{0}$ about the heteroscedasticity of the residuals (1) is rejected, the residuals have constant variance.

\begin{tabular}{llll} 
Heteroskedasticity Test: White & & \\
\hline \hline F-statistic & 2.783580 & Prob. F $(9,5)$ & 0.1360 \\
Obs*R-squared & 12.50434 & Prob. Chi-Square(9) & 0.1863 \\
Scaled explained SS & 4.238903 & Prob. Chi-Square(9) & 0.8950 \\
\hline \hline
\end{tabular}

Fig. 5. White test for the model (1)

The Durbin-Watson statistic (DW=1.82) shows the absence of autocorrelation of the residuals and the adequacy of the model (Fig. 2). The upper bound of the DW statistics $\left(\mathrm{d}_{\mathrm{u}}<1.82<4-\mathrm{d}_{\mathrm{u}}\right)$ is 1.46 at $1 \%$ significance level with 3 regressors and $\mathrm{n}=15$, and less than 2 $(1.46<1.82<4-1.46)$, therefore, there is no autocorrelation of residuals $(\mathrm{r} \approx 0)$.

Thus, the model $(1)$ is adequate and can be used to forecast $Y^{\wedge}\left(R \_D\right)$ for the short term.

It was noted during the study of the parameters and their estimates (Prob and T-stat) for building the exponential equation that the model is not adequate (Fig. 6). Therefore, this model cannot be used for research and forecast. 


\begin{tabular}{|c|c|c|c|c|}
\hline Variable & Coefficient & Std. Error & t-Statistic & Prob. \\
\hline LOG(CAP) & -1.175301 & 0.529681 & -2.218883 & 0.0485 \\
\hline LOG(NATUR) & 0.371590 & 0.553965 & 0.670783 & 0.5162 \\
\hline LOG(REV) & 0.781568 & 0.619953 & 1.260688 & 0.2335 \\
\hline $\mathrm{C}$ & 4.703603 & 5.008943 & 0.939041 & 0.3679 \\
\hline R-squared & 0.818370 & \multicolumn{2}{|c|}{ Mean dependent var } & 2.433209 \\
\hline Adjusted R-squared & 0.768834 & \multicolumn{2}{|c|}{ S.D. dependent var } & 0.978765 \\
\hline S.E. of regression & 0.470587 & \multicolumn{2}{|c|}{ Akaike info criterion } & 1.553508 \\
\hline Sum squared resid & 2.435976 & \multicolumn{2}{|c|}{ Schwarz criterion } & 1.742321 \\
\hline Log likelihood & -7.651309 & \multirow{2}{*}{\multicolumn{2}{|c|}{$\begin{array}{l}\text { Hannan-Quinn criter. } \\
\text { Durbin-Watson stat }\end{array}$}} & 1.551497 \\
\hline F-statistic & 16.52088 & & & 0.534363 \\
\hline Prob(F-statistic) & 0.000219 & & & \\
\hline
\end{tabular}

Fig. 6. The coefficients and estimates of the nonlinear equation

\section{Results}

It was found during the consideration of the actual $\mathrm{Y} i\left(\mathrm{R} \_\mathrm{D}\right)$ and fitted $\mathrm{Y} i i^{\wedge}\left(\mathrm{R} \_\mathrm{D}\right)$ values $(i=1, \ldots, 15)$ for 2005-2019 that these indicators on average slightly differ from each other. According to the annual reports of PJSC ROSNEFT [13-15] Y $\left(\mathrm{R}_{-} \mathrm{D}\right)=5.58$ billion rubles, $\mathrm{Y}^{\wedge}\left(\mathrm{R} \_\mathrm{D}\right)=5.9$ billion rubles in $2005, \mathrm{Y}\left(\mathrm{R} \_\mathrm{D}\right)=32.1$ billion rubles, $\mathrm{Y}^{\wedge}\left(\mathrm{R} \_\mathrm{D}\right)=31.4$ billion rubles in 2018, Y(R_D) $=30$ billion rubles, $\mathrm{Y}^{\wedge}\left(\mathrm{R} \_\mathrm{D}\right)=31.6$ billion rubles in 2020.

It is possible to check the correctness of the constructed linear model (1) according to the PJSC ROSNEFT report for 2020, which will be received and refined only in March 2021.

\section{Conclusions}

PJSC ROSNEFT presented the corporation's Sustainable Development Program [2-3, 13] in April 2019. The company plans to continue its course towards sustainable and innovative development, to develop projects for environmental protection.

PJSC ROSNEFT cleared a profit of 708 billion rubles according to the reports of 2019 [18-20] (the profit of 649 billion rubles in 2018, the dividend amount of 274.5 billion rubles). Sales revenue increased by $5.3 \%$ to 8,676 billion rubles.

The financial performance of PJSC ROSNEFT was expected to continue to grow in 2020-2022, and the dividend yield on equities would be around $10 \%$. However, the crisis due to COVID-19, the global decline in energy demand, cut in OPEC oil production, the partial loss of the Belarusian oil market, the termination of the corporation's participation in Venezuela projects, etc. led to significant financial losses for PJSC ROSNEFT for all the indicators in 2020.

If the consolidated financial performance of PJSC ROSNEFT for Q3 2019 is compared with that for 2020 [16], it can be noted that sales proceeds and income decreased by $37.8 \%$, net profit fell by 3 times, capital costs was down by $17.1 \%$, etc. This trend has been observed in all Russian oil and gas companies. According to the forecasts of the consulting company McKinsey\&Company, Russia's GDP will decline by $3.8 \%$ at best and $10.2 \%$ at worst in 2020.

The pandemic, oil and gas «wars», geopolitical contradictions have significantly reduced the rate of economic growth of PJSC ROSNEFT. The corporation will have to 
adjust its Programs for Sustainable and Innovative Development in order to keep costs down, stop income crash and return to at least the previous level of development $[2-3,5,7$, $9,21]$.

\section{Acknowledgements}

The publication was supported by the Russian Foundation for Basic Research, Grant No 20-01000169a

\section{References}

1. ECO brand oil. PJSC ROSNEFT. Annual reports 2019 (2019)

2. PJSC ROSNEFT: contribution to the implementation of the UN Sustainable Development Goals (2020)

3. Innovative Development Program of PJSC ROSNEFT for 2016-2020 with a prospect until 2030, https://www. rosneft.ru/

4. P.Aghion, and X. Jaravel, Econ.J., 125, 533 (2015)

5. M.Gershman, L.Gokhberg, T.Kuznetsova, \& V.Roud, Technol. Forecast. Soc. Change, 133, 132(2018)

6. A. Palangkaraya, P.H. Jensen, \& E.Webster, J. Int. Econ., 105, 1 (2017)

7. H.U.R. Khan, K.Zaman, A. Khan, \&T.Islam, Soc. Indic. Res., 133, 1165 (2017)

8. D. Lee,J. Technol. Transf., 45, 908 (2020)

9. B.S. Sergi,and etc. Modeling economic growth in contemporary Russia. Emerald Publishing Limited (2019)

10. S. Rosenzweig,J. Technol. Transf., 42, 564 (2017)

11. K.W. Willoughby, J. Technol. Transf., 45, 844 (2020)

12. N. M. Baranova, D.S. Loginova, GCPMED2019, 2, 606 (2020)

13. Sustainability Reports PJSC ROSNEFT (2006-2019), https://www. rosneft.ru/

14. Annual reports PJSC ROSNEFT (2004-2019), https://www. rosneft.ru/

15. Press-releases PJSC ROSNEFT (2005-2020), https://www. rosneft.ru/

16. Consolidated Financial Statements of PJSC ROSNEFT, https://www.rosneft.ru/

17. D.A. Ackerberg, K. Caves, G. Frazer, Econometrica, 83, 2411 (2015)

18. M. Srholec, Prague Econ.Pap., 25, 53(2016)

19. J.M. Wooldridge, Introductory econometrics: a modern approach (2015)

20. V.M. Matyushok, S. A. Balashova, I. V. Lazanyuk, Basics of econometric modeling using Eviews (2015)

21. T.Caliari, T.Chiarini, Knowledge production and economic development: Empirical evidences. J.Knowl.Econ (2016)

22. An overview of the Russian oilfield services market (2019), Deloitte

23. The world's largest companies, iFinance (2017-2019), http://global-finances.ru/ 